\title{
SBRT in Localized Renal Carcinoma: A Review of the Literature
}

\author{
CAROLINA DE LA PINTA ${ }^{1}$, RAQUEL GARCÍA LATORRE ${ }^{2}$ and RAQUEL FUENTES ${ }^{3}$ \\ ${ }^{1}$ Radiation Oncology Department, Ramón y Cajal Hospital, Madrid, Spain; \\ ${ }^{2}$ Radiology Department, Ramón y Cajal Hospital, Madrid, Spain; \\ ${ }^{3}$ Medical Oncology Department, Ramón y Cajal Hospital, Madrid, Spain
}

\begin{abstract}
Stereotactic body radiotherapy (SBRT) allows high doses of radiation to be administered in a limited number of fractions. The high doses per session might allow the theoretical radioresistance of renal carcinoma to be overcome. SBRT may be a therapeutic alternative in inoperable patients with localized renal carcinoma. This review studied the available literature on the use of SBRT in inoperable localized renal carcinoma. The review including data from English-language studies was conducted in PubMed and MEDLINE between January 2010 and December 2020. Articles were included with data from patients with renal carcinoma treated with SBRT, their indications, simulation, dose and fractionation, local control, survival and side effects, comparison with other treatments, response assessment and radioimmunotherapy. The articles included were evaluated for content and validation. The immobilization systems were variable between studies. Doses and fractions were variable from 25-26 Gy in single fractions to 21-48 Gy in 3-5 fractions, with local control being around $90 \%$ with a low rate of side-effects. We review the state of the art in SBRT for renal cell carcinoma. More research is needed to determine optimal doses and fractionation, and to develop a reliable response assessment tool. The role of radioimmunotherapy in renal carcinoma is being studied.
\end{abstract}

Renal carcinoma is the sixth most common tumor in men and the $10^{\text {th }}$ in women. Its incidence is increasing (1). The median

This article is freely accessible online.

Correspondence to: Carolina de la Pinta, Radiation Oncology Department, Ramón y Cajal Hospital, Madrid, Spain. E-mail: cdelapinta88@gmail.com

Key Words: Kidney, renal cell carcinoma, SBRT, SABR, review. age at diagnosis is 64 years. The World Health Organization subdivides renal carcinomas into more than 40 subtypes (2). Approximately $90 \%$ of renal tumors are carcinomas and out of these, $80 \%$ are clear-cell carcinomas; other less common types include papillary renal carcinoma, chromophobic carcinoma, transitional cell carcinoma of the renal pelvis and Bellini's duct carcinoma. Renal carcinomas most often originate in the renal cortex. Their diagnosis has been increased by the advancement of diagnostic imaging. Risk factors involved in their development include smoking, hypertension, obesity, dialysis, chronic pain medication use, chemotherapy, and infection with hepatitis C virus (2-4). The most important prognostic factors that determine 5-year survival are the tumor stage, grade and local extent, the presence of involved nodes and the presence of metastases (5).

The 5-year survival rate for patients with localized lesions is greater than $90 \%$. Traditionally, renal carcinoma is considered resistant to radiotherapy and chemotherapy. The development of targeted treatments such as sunitinib, temsirolimus, bevacizumab, interferon alpha or sorafenib has improved the outcomes. There are alternatives in patients considered non-surgical due to their comorbidities or unresectable tumors, such as active surveillance, cryotherapy, radiofrequency or microwave ablation, and, more recently, stereotactic body radiotherapy (SBRT). Active surveillance would include patients with small, inoperable tumors with limited life expectancy. Radiofrequency ablation is used for tumors of less than 3-3.5 cm, separated from the renal hilum, after partial nephrectomy, in monorenal or kidney transplant patients. Invasive ablative techniques can cause stenosis, fistulas and bleeding (6). SBRT can be used for large, central tumors, with proximity to vessels and ureter, and can be advantageous in patients taking anticoagulants and the elderly population, being a non-invasive technique with a low toxicity profile. The use of SBRT increased from 2004 to 2013 from $25 \%$ to $95.4 \%$ as shown by Haque et al. (7). 
This review focuses on the use of SBRT for primary renal carcinoma. This study discusses the challenges and opportunities presented by SBRT, in terms of its indications, technical considerations, clinical outcomes, and safety data. It is compared with other local techniques and in assessment of the response. It is hoped that this review can provide guidance to both established and developing SBRT practitioners and centers.

\section{Methodology}

We conducted a review including data from prospective and retrospective studies, meta-analyses, reviews, and systematic reviews of English language studies in PubMed and MEDLINE between January 2010 and December 2020. The MeSH term utilized were SBRT OR SABR AND renal cell carcinoma OR RCC. We examined 150 articles. We included studies by analyzing the abstract text. After examining them, the articles that met the selection criteria were included: Series with renal cell carcinoma, local control, and toxicity data, published in the past 10 years. Finally, 42 articles were included. Most were retrospective studies. Articles were included with data from patients with renal carcinoma treated with SBRT, their indications, simulation, dose and fractionation, local control, survival and side-effects, comparison with other treatments, response assessment and radioimmunotherapy.

\section{Results of the Review}

Indications for SBRT in localized renal cell carcinoma. Recently, Muller et al. published guidelines for radiation therapy in renal carcinoma, dividing the possible indications of renal SBRT (8). SBRT provides local control at 2 years in more than $90 \%$ of such cases in small renal masses. In patients with oligometastatic disease, treatment with SBRT is possible after discussion in a multidisciplinary committee. Radiation therapy in palliative and symptomatic sittings is indicated as for other tumors. In the future, SBRT will have its role in medically inoperable patients with renal carcinoma and in patients with oligometastatic disease. Neither the European Society of Medical Oncology (9) nor National Comprehensive Cancer Network (6) recommend this treatment as an alternative to surgery or ablative techniques.

Indications for renal SBRT would include inoperable patients as an ablative alternative in those with preserved renal function [glomerular filtration rate $(\mathrm{GFR}) \geq 70 \mathrm{ml} / \mathrm{min}$ ] and lesions $\geq 1.5 \mathrm{~cm}$ and $\leq 7 \mathrm{~cm}$.

Immobilization and simulation. For conventional linear accelerator treatment, the placement of fiducial markers is optional; if fiducial markers are used, ideally three are needed, one for each dimension and they are usually placed in the Diagnostic Radiology Department by the interventional radiology team. After the placement of the fiducials, it is recommended to delay the planning computed tomography (CT) from 1 week to 10 days. The planning CT is performed with intravenous contrast if the patient's renal function allows it. The patient is placed in a supine position, arms on each side of the head, with an alpha cradle or vacuum mattress and an abdominal compression system.

In units such as CyberKnife ${ }^{\circledR}$, three to six fiducial markers must be placed on a mandatory basis; after placing them, the planning CT scan is delayed from 7 to 10 days. The planning CT scan is performed with the patient in a supine position, with the arms along the body, and it is not necessary to use an abdominal compression system thanks to the tracking performed by the unit $(4-5,10-27)$.

Dose and fractionation. The optimal dose and fractionation have not been established. Studies employed doses from $25-$ 26 Gy in single fractions to 21-48 Gy in 3-5 fractions. Ponsky et al. in their phase I dose escalation study in 19 patients compared 24, 32, 40 and 48 Gy in 4 fractions, demonstrating that $48 \mathrm{~Gy}$ in 4 fractions can be applied without dose-limiting toxicity, with a partial response rate of $20 \%$ and a stable disease rate of $80 \%$ (11). With these data, a dose-escalation study was designed at $60 \mathrm{~Gy}$ in 3 fractions. The study by Siva et al. showed that use of the single dose was not related to a worse kidney function (4).

Local control and survival. Local control (LC) ranged from $84-100 \%$ according to series, with up to 5 years of follow-up in some of them. In a systematic review of Siva et al., 126 patients with inoperable renal carcinoma treated with SBRT in 1-6 fractions were analyzed, $40 \mathrm{~Gy}$ in 5 fractions being the scheme most used. The median and mean follow-up ranged from 9 to 57.5 months. After reviewing, 161 articles, three prospective and seven retrospective articles were included. An LC of $84-100 \%$ was demonstrated (12). In a prospective study by Staehler et al., 40 patients with 45 unresectable lesions smaller than $4 \mathrm{~cm}$ were treated with CyberKnife ${ }^{\circledR}$ in a single dose of 25 Gy at $70 \%$ isodose. The median follow-up was 28.1 months. An $86.7 \%$ remission was achieved, with $42.2 \%$ complete responses (13). In a study by Chang et al., 16 patients were treated with SBRT of 30-40 Gy in 5 fractions. Eleven patients presented stable disease after treatment, four patients showed partial response, and no patients showed progression. The median follow-up was 19 months (range=730 months) and showed LC was $100 \%$ (14). Siva et al. published a prospective trial with 37 patients with histologically confirmed renal carcinoma $(92 \%)$ with T1a in $35 \%$, T1b in $62 \%$, and T2a in $3 \%$. One patient presented with bilateral tumor. They used doses of $26 \mathrm{~Gy}$ in a single fraction or 42 Gy in 3 fractions, and $89 \%$ of the patients were able to complete the treatment. The median follow-up was 24 months. The 2-year LC, progression-free survival (PFS), and overall 
survival (OS) rates were $100 \%, 89 \%$, and $92 \%$ (15). In a subsequent study by the same authors, 223 patients from nine centers were included; 118 patients were treated with a single dose of 25 Gy [biologically effective dose (BED)=87.5 Gy] and 105 patients with $40 \mathrm{~Gy} / 2-10$ fractions (median $\mathrm{BED}=80$ Gy). At 4 years, the LC, cancer-specific survival (CSS), and OS rates were $97.8 \%, 91.9 \%$, and $70.7 \%$, respectively (4).

Correa et al. included 11 patients treated with 25-40 Gy in 35 fractions. The median planning target volume was $9.5 \mathrm{cc}$ (range=7.5-24.4 cc). The median follow-up was 3.9 years. Seven patients were evaluable at follow-up, five with stable disease, one with partial response, and one with progression. The median survival was 20.4 months (16). Peddada et al. reported their experience with a total of 21 patients treated with 48 Gy SBRT in 3 fractions. Fourteen of the patients refused surgery. Two patients had transitional cell carcinoma and 19 patients had renal cell carcinoma. The median follow-up was 78 months (range=5107 months). At 5 years, the LC rate was $100 \%$. Tumor size had decreased a median of $5.3 \%$ at 1 year, $15.6 \%$ at 2 years, and $15.4 \%$ at 5 years (17). In another study, Correa et al. included 81 monorenal patients and found LC, PFS, CSS and OS rates of $98 \%, 77.5 \%, 98.2 \%$, and $81.5 \%$ at 2 years (18). Siva et al. investigated the role of SBRT in renal carcinoma larger than 4 $\mathrm{cm}(>\mathrm{T} 1 \mathrm{~b})$. They included patients from nine centers, a total of 95 patients with a median follow-up of 2.7 years. The median tumor diameter was $4.9 \mathrm{~cm}$ and $81.1 \%$ of the patients had an Eastern Cooperative Oncology Group performance score of 0$1 ; 77.6 \%$ of the tumors were defined as inoperable. Local, remote and any failure at 4 years were $2.9 \%, 11.1 \%$ and $12.1 \%$. The CSS, OS, and PFS were $96.1 \%, 83.7 \%$, and $81 \%$ at 2 years and $91.4 \%, 69.2 \%, 64.9 \%$ at 4 years, respectively. Multivariate analysis showed that increased tumor size was associated with reduced CSS (19). Wegner et al. published data from the National Cancer Database from 2004 to 2016. They included 347 patients with tumors of a median size of $3.8 \mathrm{~cm}$, treated with 34-54 Gy in 1-5 fractions. The median follow-up was 36 months (range $=1-156$ months). Predictors of reduced survival included age $>74$ years, large tumor, and N1 or M1 stage. The median survival was 58 months. The median survival for those with tumors $\leq 2.5 \mathrm{~cm}, 2.6-3.5 \mathrm{~cm}$, and more than $5 \mathrm{~cm}$ was 92,88 , 44 , and 26 months $(p<0.0001)(20)$.

Most of the available studies used SBRT with photons. There were some studies with charged particles, however, our review did not focus on these. The dosimetric advantages of protons and carbon ions compared to photon irradiation have been demonstrated in many studies. However, whether these advantages lead to improved clinical results in localized renal cell carcinoma needs to be studied in clinical trials (21). Table I summarizes the most important studies.

We are awaiting the results of the prospective, multiinstitutional, phase II FASTRACKII clinical trial, aiming to recruit 70 patients with renal carcinoma confirmed by biopsy and medical inoperability or rejection of surgery (22).

\section{Adverse Events}

Non-renal adverse events. In the systematic review by Siva et al., the grade 1-2 non-renal toxicities were $21.4 \%$, with a grade 3 toxicity of $3.8 \%$ or higher (12). Pham et al. in their phase I study evaluated the safety of SBRT treatment in 20 patients. The doses used were from $26 \mathrm{~Gy}$ in a single fraction to 42 Gy in 3 fractions. Eight patients did not present toxicity, the rest presented grade 1 and 2 toxicities in the first 6 months after treatment. There were no grade 3-4 toxicities (23). The study by Chang et al. included 16 patients. The authors reported one patient with acute nausea. Four patients had symptoms before SBRT and resolved after it (14). Siva et al. in 2017 included 37 patients; nonrenal toxicities included minor toxicities in $78 \%$ of patients, with acute grade 1 fatigue and late grade 1 chest wall pain being the most common. Severe toxicities were rare, with only one patient experiencing late G3 fatigue. No G4-5 toxicities were observed (15). Correa et al. included 11 patients with tumors of $9.5 \mathrm{~cm}$ median planning target volume, five patients presented grade 1 toxicity, the patient with the largest tumor grade 2 diarrhea and grade 3 nausea (16). Siva et al. reported non-renal grade 3 and 4 toxicity of $1.3 \%$ (4). Peddada et al. reported grade 1 toxicity of $14.2 \%$, with no other adverse events (17). Siva et al. included 38 patients, $40 \%$ had grade 1-2 toxicities. There were no grade 3-5 toxicities (19).

Patients with preserved renal function before SBRT. The impact of SBRT on renal function is very important. Dialysis rates after SBRT in renal carcinoma are low $(24,25)$. There are some data suggesting that there is a dose-response relationship, with minimal deterioration of kidney function, seen in patients receiving $10 \mathrm{~Gy}$ or less in a single fraction, and with doses above 100 Gy (BED3). Siva et al. related the $\mathrm{R} 50 \%$, which is a derived unitless quantity obtained from the volume of the $50 \%$ prescription isodose cloud, compliance index to the decrease in GFR, which may be a parameter to consider (24). In their 25 Gy single-dose study on 45 tumors, Staehler et al. reported no patients with impaired renal function, although the study had a median follow-up of 28.1 months and did not include tumors larger than $4 \mathrm{~cm}$ (13). Siva et al. included 37 patients with mildly impaired renal function, which dropped to $44 \mathrm{ml} / \mathrm{min}$ at 1 and 2 years $(p<0.001)$ (15). Peddada et al. observed a decrease in GFR with a median of $1.5 \%$ at 1 year, $7 \%$ at 2 years, and $14.2 \%$ at 5 years (17). After the treatment of 13 lesions in 10 patients, Senger et al. demonstrated stability of renal function of $51.3 \pm 19.7 \mathrm{ml} / \mathrm{min}$ baseline and $51.6 \pm 25.8 \mathrm{ml} / \mathrm{min}$ follow-up (26). On the other hand, Siva et al. observed a slight decrease in GFR (4). However, GFR was improved in $26.5 \%$ (4). In the study by Siva et al., an increase in GFR was described in 18 patients (20\%); it was not observed with nephrectomy or radiofrequency due to a possible 
Table I. Studies of stereotactic body radiotherapy in renal carcinoma.

\begin{tabular}{|c|c|c|c|c|c|c|c|}
\hline Study & Type & $\mathrm{n}$ & Mean size & Dose $\times$ fractions & Local control & Overall survival & Toxicity \\
\hline Kaplan et al., 2010 (28) & Prospective (Phase I) & 12 & NR & $21-39$ Gy $\times 3$ & $91.7 \%$ & NR & None $>$ G1 \\
\hline Nair et al., 2013 (29) & Retrospective & 3 & $21.3 \mathrm{~cm}^{3}$ & $39 \mathrm{~Gy} \times 3$ & $100 \%$ At 1 year & NR & No \\
\hline McBride et al., 2013 (30) & Prospective (Phase I) & 15 & $3.4 \mathrm{~cm}$ & $21-48$ Gy $\times 3$ & $87 \%$ & NR & $\begin{array}{c}\text { Late } \mathrm{G} 1, \mathrm{n}=1 \\
\text { Renal dysfunction } \\
\mathrm{n}=3 \text {. }\end{array}$ \\
\hline Pham et al., 2014 (23) & Prospective & 20 & $\begin{array}{c}3-9 \mathrm{~cm} \\
(\text { range }=22.7- \\
\left.322.5 \mathrm{~cm}^{3}\right)\end{array}$ & $\begin{array}{l}42 \mathrm{~Gy} \times 3 \\
26 \mathrm{~Gy} \times 1\end{array}$ & NR & NR & $60 \%$ G1-2 \\
\hline Wang et al., 2014 (31) & Retrospective & 9 & $4 \mathrm{~cm}$ & $\begin{array}{c}36-51 \text { Gy } \\
\times 10-17\end{array}$ & $\begin{array}{c}64.8 \%, 43.2 \% \\
\text { And } 43.2 \% \\
\text { at } 1,3,5 \text { years }\end{array}$ & $\begin{array}{c}66.7,53.3, \\
35.6 \% \text { At } 1, \\
3 \text { and } 5 \text { years }\end{array}$ & $\begin{array}{c}\text { Acute toxicity: G1 } \\
\text { leukocytopenia, } \\
\mathrm{n}=2, \mathrm{G} 1 \\
\text { gastrointestinal, } \\
\mathrm{n}=2 \text {. } \\
\text { G2 late toxicities, } \\
\mathrm{n}=2\end{array}$ \\
\hline Lo et al., 2014 (32) & Retrospective & 3 & $4.77 \mathrm{~cm}$ & 40 Gy $\times 5$ & $100 \%$ & $100 \%$ At 1 year & $\begin{array}{l}\text { Acute } \mathrm{G} 1, \mathrm{n}=1 \\
\text { No grade } 3\end{array}$ \\
\hline Ponsky et al., 2015 (11) & $\begin{array}{l}\text { Prospective } \\
\text { (Phase I) }\end{array}$ & 19 & NR & $48 \mathrm{~Gy} \times 4$ & NR & NR & $\begin{array}{c}5.2 \% \mathrm{G} 2 \\
15.8 \% \mathrm{G} 3-4\end{array}$ \\
\hline Staehler et al., 2015 (13) & Prospective & 40 & $7.5-120 \mathrm{~cm}$ & $25 \mathrm{~Gy} \times 1$ & $98 \%$ At 9 months & $\begin{array}{l}\text { Not attained } \\
\text { after } \\
28.1 \text { months }\end{array}$ & $13 \% \mathrm{G} 1-2$ \\
\hline Chang et al., 2016 (14) & Retrospective & 16 & & $30-40$ Gy $\times 5$ & $100 \%$ & NR & $\begin{array}{c}\text { Acute } \mathrm{G} 2, \mathrm{n}=1 \\
\text { Late } \mathrm{G} 4, \mathrm{n}=2\end{array}$ \\
\hline Siva et al., 2017 (15) & Prospective & 33 & NR & $\begin{array}{l}26 \mathrm{~Gy} \times 1 \\
42 \mathrm{~Gy} \times 3\end{array}$ & $\begin{array}{c}100 \% \text { At } \\
2 \text { years }\end{array}$ & $\begin{array}{l}92 \% \text { At } \\
2 \text { years }\end{array}$ & $\begin{array}{c}78 \% \text { G1-2 } \\
3 \% \text { G3 } \\
\text { No G4 }\end{array}$ \\
\hline Correa et al., 2018 (16) & Retrospective & 11 & $\begin{array}{c}9.5 \mathrm{~cm} \\
\text { (range }=7.5- \\
24.4 \mathrm{~cm})\end{array}$ & $25-40$ Gy $\times 5$ & & $\begin{array}{c}\text { Median= } \\
20.4 \text { months }\end{array}$ & $\begin{array}{c}\mathrm{G} 1, \mathrm{n}=5 \\
\mathrm{G} 2 \text { diarrhea and } \\
\mathrm{G} 3 \text { nausea, } \mathrm{n}=1\end{array}$ \\
\hline Peddada et al., 2019 (17) & Prospective & 21 & NR & 48 Gy $\times 3$ & $100 \%$ & & $\mathrm{G} 1, \mathrm{n}=3$ \\
\hline Senger et al., 2019 (26) & Retrospective & $\begin{array}{c}10 \\
(13 \\
\text { lesions })\end{array}$ & NR & $\begin{array}{c}24-25 \text { Gy } \times 1 \\
36 \text { Gy } \times 3\end{array}$ & $\begin{array}{l}92.3 \% \text { Of all } \\
\text { lesions at } \\
27 \text { months }\end{array}$ & NR & $\begin{array}{l}\text { Renal function } \\
\text { stable }\end{array}$ \\
\hline Funayama et al., 2019 (33) & Prospective & 13 & $9-43 \mathrm{~mm}$ & $60-70 \mathrm{~Gy} \times 10$ & $\begin{array}{c}92.3 \% \text { At } \\
3 \text { years }\end{array}$ & $\begin{array}{c}91.7 \% \text { At } \\
2 \text { years } \\
71.3 \% \text { At } \\
3 \text { years }\end{array}$ & $\begin{array}{l}\text { Mild/moderate } \\
\text { decrease in } \\
\text { renal function. } \\
\text { G4-5, } n=2\end{array}$ \\
\hline
\end{tabular}

NR: Not reported. G: grade.

compensatory hyperfiltration mechanism of the functioning nephrons. The mean GFR was $57.2 \mathrm{ml} / \mathrm{min}$, after SBRT it decreased by $7.9 \mathrm{ml} / \mathrm{min}$ and three patients required dialysis, none was monorenal) (19).

Renal atrophy, defined by the change in kidney volume, is another measure of kidney dysfunction that has been studied in relation to the effects of radiation therapy. Renal atrophy after SBRT was studied in the study by Yamamoto et al. The authors demonstrated strong correlation after SBRT between V20 and $\mathrm{V} 30$ and renal atrophy. Attention should be paid to the dose distribution of 20-30 Gy in 10 fractions in SBRT in renal carcinoma. Fiducial marking may be beneficial in reducing renal atrophy. There was no major grade 2 renal toxicity (27).
Patients with impaired renal function prior to SBRT. Small data series are emerging indicating that even in patients with preexisting kidney damage, SBRT may be a safe strategy. One study included nine patients treated with SBRT with GFR of $52 \mathrm{ml} / \mathrm{min}$ who were considered at high risk of requiring postoperative dialysis (24). A significant reduction in GFR was observed after SBRT to $43 \mathrm{ml} / \mathrm{min}$; no patients required dialysis. Another small study of three patients with even poorer kidney function, with GFRs between 17.51 and $34.79 \mathrm{ml} / \mathrm{min}$, used CyberKnife ${ }^{\circledR}$-based SBRT to administer 40 Gy in 5 fractions (32). In this study, one patient with a GFR of 17.51 $\mathrm{ml} / \mathrm{min}$ experienced a reduction in GFR at 26 months to 12.28 $\mathrm{ml} / \mathrm{min}$. The ipsilateral kidney received $28 \% \mathrm{~V} 15 \mathrm{~Gy}$. The 
other two patients experienced a small reduction in GFR to 30 $\mathrm{ml} / \mathrm{min}$, not requiring dialysis. No patient experienced local failure. Recently, the International Radiosurgery Oncology Consortium for Kidney performed a multicenter analysis investigating SBRT for renal cell carcinoma in 81 patients with a solitary kidney with an excellent oncologic outcome. The mean GFR rate decreased from $64.6 \pm 21.7$ to $59.2 \pm 23.9$ $\mathrm{ml} / \mathrm{min} / 1.73 \mathrm{~m}^{2}$ after a median of 20.4 months, and no patients required dialysis after treatment. Interestingly, 26.2\% of patients experienced an increase in their GFR rate (18). However, Chang et al. reported two patients with grade 4 renal toxicity in patients with previous chronic renal disease (14).

These small series provide encouraging results, although more data on patients with pre-existing renal dysfunction and the establishment of safe limitations are needed to better predict renal outcomes after treatment.

\section{Comparison With Other Treatments}

Radiofrequency ablation and cryoablation are local therapeutic alternatives for inoperable, small renal carcinomas or patients who refuse surgery. Other techniques such as microwave ablation or high-intensity focused ultrasound are experimental and only reported in small case series. Radiofrequency ablation and microwave ablation are limited to small renal carcinomas up to $4 \mathrm{~cm}$ in diameter, whereas cryoablation may be an alternative for larger tumors. However, the rate of complications and the probability of tumor recurrence after cryoablation increased when the tumor size exceeded $3.5 \mathrm{~cm}$ or $3 \mathrm{~cm}$, respectively.

There is an absence of randomized controlled trials comparing thermal ablation techniques and SBRT for renal carcinoma; only indirect comparisons of retrospective and prospective series are possible. Local control rates were repeatedly similar among the different local treatments. The rate of complications associated with radiofrequency ablation was around $6.6 \%$, including bleeding, nerve damage (3.9\%), ureteral stenosis $(2.1 \%)$, and urine leakage $(34,35)$. Complications after microwave ablation are similar to those of radiofrequency ablation, occurring in 3-17\%, including perirenal hematoma, urinoma, or skin dysesthesia (35). Bleeding is possible with cryoablation (34).

Comparison between treatments is a major challenge, as the criteria for tumor recurrence are different. For example, after radiofrequency ablation, any contrast enhancement is considered recurrence, whereas after SBRT, enhancement may persist even when the tumor is stable or controlled.

\section{Evaluation After Treatment}

The evaluation of the tumor response after SBRT in renal carcinoma is complicated. Ionizing radiation can cause a delay in cell death through mechanisms such as mitotic catastrophe, and viable tumor cells can be found soon after SBRT (36). In diagnostic tests, contrast enhancement in CT can persist for a long period after treatment, and it is not a diagnostic parameter for treatment failure (37). Tumor size is not an adequate criterion either for follow-up after SBRT, and pseudoprogression may develop, with an increase in size in the initial 3 to 6 months, due to initial inflammation after treatment.

Given these uncertainties, assessments at 6 months after treatment are recommended, and the use of absence of progression instead of response to assess the success of the treatment. Other strategies include follow-up with magnetic resonance imaging or positron-emission tomography (38). Response evaluation times and follow-up serum biomarkers are being studied.

\section{Radioimmunotherapy}

The treatment of metastatic renal carcinoma has changed significantly in recent years with the development of immunotherapy. SBRT induces microvascular damage, which increases the cytotoxic effect of radiotherapy. Renal carcinoma is a highly vascularized tumor and angiogenesis is central to its development and progression. Vascular damage and functional disruption of the vascular endothelium allows for greater penetration of systemic treatment (39). In addition, the abscopal effect, which consists of regression of metastases in areas away from the radiotherapy site, has been described in renal carcinoma treated with SBRT and hypofractionation (40).

The phase III Checkmate 025 study demonstrated the efficacy of immunotherapy in metastatic renal carcinoma compared to everolimus in patients previously treated with antiangiogenic drugs, improving OS from 19.6 months to 25 months and establishing it as the standard second-line treatment (41). Checkmate 214 demonstrated superior OS with the combination of nivolumab and ipilimumab compared to sunitinib in previously untreated patients (42). The KEYNOTE-426 study demonstrated longer survival with the combination of pembrolizumab and axitinib compared to sunitinib $(43,44)$. Following these studies, ipilimumab, pembrolizumb, and avelumab have been approved and others are under study for metastatic renal carcinoma (45).

Some trials in metastatic renal carcinoma have demonstrated the safety of combination radioimmunotherapy. A phase I study combining pembrolizumab and SBRT in patients with advanced tumours who progressed on standard treatment showed an abscopal effect in $13.3 \%$ of patients (46). The phase II NIVES study is evaluating the combination of immunotherapy and SBRT in metastatic renal carcinoma (47) and the RADVAX study is evaluating the combination 
of nivolumab and ipilimumab with SBRT (48). Two studies currently underway are the CYTOSHRINK study, a phase II study involving patients with advanced renal carcinoma who decline cytoreductive nephrectomy, with patients receiving nivolumab or ipilimumab (ClinicalTrials .gov Identifier: NCT04090710) and SBRT to the primary renal lesion or immunotherapy alone, and the RAPPORT study, a phase I/II study of radiotherapy and pembrolizumab in patients with oligometastatic renal carcinoma (ClinicalTrials.gov Identifier: NCT02855203). The combination of radiotherapy and immunotherapy has important advantages and theoretical benefits; however, more studies are needed to support this hypothesis and allow for adequate patient selection.

\section{Limitations}

The limitations of this review include the nature of the studies, most were retrospective series or small prospective series, very heterogeneous with different criteria for inclusion and response assessment. Some prognostic factors for renal carcinoma include size or previous renal function, and numerous studies included heterogeneous patients, complicating the establishment of conclusions. In addition, limited and ambiguous information makes it difficult to interpret the data.

\section{Conclusion}

Radiation therapy in renal cancer has been relegated to palliative treatments. SBRT in inoperable renal carcinoma with doses between 25-26 Gy in a single fraction, with up to 21-48 Gy in 3-5 fractions achieves important LC, with low non-renal toxicity and mild toxicity in renal function, even in patients with poor basal renal function. There are no comparative studies with other ablative techniques, but indirect comparisons show similar results in LC and sideeffects. Post-treatment response assessment is complex and should be delayed for up to 6 months. More studies are needed to establish SBRT in renal carcinoma as an alternative in these patients and its combination with immunotherapy.

\section{Conflicts of Interest}

The Authors declare they have no conflicts of interest.

\section{Authors' Contributions}

Conceptualization, data curation and formal analysis: Raquel Fuentes. Data curation, formal analysis, methodology: Raquel García Latorre. Conceptualization, data curation, formal analysis, methodology, supervision, writing - original draft, writing - review and editing: Carolina de la Pinta.

\section{References}

1 Globocan database. Available at: https://gco.iarc.fr [Last accessed on January 11, 2022]

2 Capitanio U, Bensalah K, Bex A, Boorjian SA, Bray F, Coleman J, Gore JL, Sun M, Wood C and Russo P: Epidemiology of renal cell carcinoma. Eur Urol 75(1): 74-84, 2019. PMID: 30243799. DOI: $10.1016 /$ j.eururo.2018.08.036

3 Nabi S, Kessler ER, Bernard B, Flaig TW and Lam ET: Renal cell carcinoma: a review of biology and pathophysiology. F1000Res 7: 307, 2018. PMID: 29568504. DOI: 10.12688/f1000research. 13179.1

4 Siva S, Louie AV, Warner A, Muacevic A, Gandhidasan S, Ponsky L, Ellis R, Kaplan I, Mahadevan A, Chu W, Swaminath A, Onishi H, Teh B, Correa RJ, Lo SS and Staehler M: Pooled analysis of stereotactic ablative radiotherapy for primary renal cell carcinoma: A report from the International Radiosurgery Oncology Consortium for Kidney (IROCK). Cancer 124(5): 934-942, 2018. PMID: 29266183. DOI: $10.1002 /$ cncr.31156

5 Kothari G, Louie AV, Pryor D, Vela I, Lo SS, Teh BS and Siva S: Stereotactic body radiotherapy for primary renal cell carcinoma and adrenal metastases. Chin Clin Oncol 6(Suppl 2): S17, 2017. PMID: 28917255. DOI: $10.21037 /$ cco.2017.06.30

6 Motzer RJ, Jonasch E, Michaelson MD, Nandagopal L, Gore JL, George S, Alva A, Haas N, Harrison MR, Plimack ER, Sosman J, Agarwal N, Bhayani S, Choueiri TK, Costello BA, Derweesh IH, Gallagher TH, Hancock SL, Kyriakopoulos C, LaGrange C, Lam ET, Lau C, Lewis B, Manley B, McCreery B, McDonald A, Mortazavi A, Pierorazio PM, Ponsky L, Redman BG, Somer B, Wile G, Dwyer MA, Hammond LJ and Zuccarino-Catania G: NCCN Guidelines Insights: Kidney Cancer, Version 2.2020. J Natl Compr Canc Netw 17(11): 1278-1285, 2019. PMID: 31693980. DOI: 10.6004/jncen.2019.0054

7 Haque W, Verma V, Lewis GD, Lo SS, Butler EB and Teh BS: Utilization of radiotherapy and stereotactic body radiation therapy for renal cell cancer in the USA. Future Oncol 14(9): 819-827, 2018. PMID: 29527938. DOI: 10.2217/fon-2017-0536

8 Müller AC, van Oorschot B, Micke O and Guckenberger M: German S3 guideline for renal cell carcinoma: Presentation and discussion of essential aspects for the radiation oncologist. Strahlenther Onkol 194(1): 1-8, 2018. PMID: 28819766. DOI: 10.1007/s00066-017-1185-y

9 Escudier B, Porta C, Schmidinger M, Rioux-Leclercq N, Bex A, Khoo V, Grünwald V, Gillessen S, Horwich A and ESMO Guidelines Committee: Renal cell carcinoma: ESMO Clinical Practice Guidelines for diagnosis, treatment and follow-up $\dagger$. Ann Oncol 30(5): 706-720, 2019. PMID: 30788497. DOI: 10.1093/ annonc/mdz056

10 Sonier M, Chu W, Lalani N, Erler D, Cheung P and Korol R: Evaluation of kidney motion and target localization in abdominal SBRT patients. J Appl Clin Med Phys 17(6): 429-433, 2016. PMID: 27929514. DOI: 10.1120/jacmp.v17i6.6406

11 Ponsky L, Lo SS, Zhang Y, Schluchter M, Liu Y, Patel R, Abouassaly R, Welford S, Gulani V, Haaga JR, Machtay M and Ellis RJ: Phase I dose-escalation study of stereotactic body radiotherapy (SBRT) for poor surgical candidates with localized renal cell carcinoma. Radiother Oncol 117(1): 183187, 2015. PMID: 26362723. DOI: 10.1016/j.radonc. 2015.08.030 
12 Siva S, Pham D, Gill S, Corcoran NM and Foroudi F: A systematic review of stereotactic radiotherapy ablation for primary renal cell carcinoma. BJU Int 110(11 Pt B): E737-E743, 2012. PMID: 23107102. DOI: 10.1111/j.1464-410X.2012.11550.x

13 Staehler M, Bader M, Schlenker B, Casuscelli J, Karl A, Roosen A, Stief CG, Bex A, Wowra B and Muacevic A: Single fraction radiosurgery for the treatment of renal tumors. J Urol 193(3): 771775, 2015. PMID: 25132240. DOI: 10.1016/j.juro.2014.08.044

14 Chang JH, Cheung P, Erler D, Sonier M, Korol R and Chu W: Stereotactic ablative body radiotherapy for primary renal cell carcinoma in non-surgical candidates: initial clinical experience. Clin Oncol (R Coll Radiol) 28(9): e109-e114, 2016. PMID: 27131756. DOI: 10.1016/j.clon.2016.04.002

15 Siva S, Pham D, Kron T, Bressel M, Lam J, Tan TH, Chesson B, Shaw M, Chander S, Gill S, Brook NR, Lawrentschuk N, Murphy DG and Foroudi F: Stereotactic ablative body radiotherapy for inoperable primary kidney cancer: a prospective clinical trial. BJU Int 120(5): 623-630, 2017. PMID: 28188682. DOI: $10.1111 /$ bju.13811

16 Correa RJM, Rodrigues GB, Chen H, Warner A, Ahmad B and Louie AV: Stereotactic ablative radiotherapy (SABR) for large renal tumors: a retrospective case series evaluating clinical outcomes, toxicity, and technical considerations. Am J Clin Oncol 41(6): 568-575, 2018. PMID: 27635623. DOI: 10.1097/COC.0000000000000329

17 Peddada AV, Anderson D, Blasi OC, McCollough K, Jennings SB and Monroe AT: Nephron-sparing robotic radiosurgical therapy for primary renal cell carcinoma: single-institution experience and review of the literature. Adv Radiat Oncol 5(2): 204-211, 2019. PMID: 32280820. DOI: 10.1016/j.adro.2019.10.001

18 Correa RJM, Louie AV, Zaorsky NG, Lehrer EJ, Ellis R, Ponsky L, Kaplan I, Mahadevan A, Chu W, Swaminath A, Hannan R, Onishi H, Teh BS, Muacevic A, Lo SS, Staehler M and Siva S: The emerging role of stereotactic ablative radiotherapy for primary renal cell carcinoma: a systematic review and metaanalysis. Eur Urol Focus 5(6): 958-969, 2019. PMID: 31248849. DOI: $10.1016 /$ j.euf.2019.06.002

19 Siva S, Correa RJM, Warner A, Staehler M, Ellis RJ, Ponsky L, Kaplan ID, Mahadevan A, Chu W, Gandhidasan S, Swaminath A, Onishi H, Teh BS, Lo SS, Muacevic A and Louie AV: Stereotactic ablative radiotherapy for $\geq \mathrm{T} 1 \mathrm{~b}$ primary renal cell carcinoma: a report from the International Radiosurgery Oncology Consortium for Kidney (IROCK). Int J Radiat Oncol Biol Phys 108(4): 941-949, 2020. PMID: 32562838. DOI: 10.1016/j.ijrobp.2020.06.014

20 Wegner RE, Abel S, Vemana G, Mao S and Fuhrer R: Utilization of stereotactic ablative body radiation therapy for intact renal cell carcinoma: trends in treatment and predictors of outcome. Adv Radiat Oncol 5(1): 85-91, 2019. PMID: 32051894. DOI: 10.1016/j.adro.2019.07.018

21 Baydoun A, Vapiwala N, Ponsky LE, Awan M, Kassaee A, Sutton D, Podder TK, Zhang Y, Dobbins D, Muzic RF Jr, Traughber B, Machtay M and Ellis R: Comparative analysis for renal stereotactic body radiotherapy using Cyberknife, VMAT and proton therapy based treatment planning. J Appl Clin Med Phys 19(3): 125-130, 2018. PMID: 29542260. DOI: 10.1002/acm2.12308

22 Siva S, Chesson B, Bressel M, Pryor D, Higgs B, Reynolds HM, Hardcastle N, Montgomery R, Vanneste B, Khoo V, Ruben J, Lau E, Hofman MS, De Abreu Lourenco R, Sridharan S, Brook NR, Martin J, Lawrentschuk N, Kron T and Foroudi F: TROG
15.03 phase II clinical trial of Focal Ablative STereotactic Radiosurgery for Cancers of the Kidney - FASTRACK II. BMC Cancer 18(1): 1030, 2018. PMID: 30352550. DOI: 10.1186/s 12885-018-4916-2

23 Pham D, Thompson A, Kron T, Foroudi F, Kolsky MS, Devereux T, Lim A and Siva S: Stereotactic ablative body radiation therapy for primary kidney cancer: a 3-dimensional conformal technique associated with low rates of early toxicity. Int J Radiat Oncol Biol Phys 90(5): 1061-1068, 2014. PMID: 25442039. DOI: 10.1016/j.ijrobp.2014.07.043

24 Siva S, Jackson P, Kron T, Bressel M, Lau E, Hofman M, Shaw M, Chander S, Pham D, Lawrentschuk N, Wong LM, Goad J and Foroudi F: Impact of stereotactic radiotherapy on kidney function in primary renal cell carcinoma: Establishing a doseresponse relationship. Radiother Oncol 118(3): 540-546, 2016. PMID: 26873790. DOI: 10.1016/j.radonc.2016.01.027

25 Jackson P, Foroudi F, Pham D, Hofman MS, Hardcastle N, Callahan J, Kron T and Siva S: Short communication: timeline of radiation-induced kidney function loss after stereotactic ablative body radiotherapy of renal cell carcinoma as evaluated by serial (99m)Tc-DMSA SPECT/CT. Radiat Oncol 9: 253, 2014. PMID: 25424613. DOI: 10.1186/s13014-014-0253-Z

26 Senger C, Conti A, Kluge A, Pasemann D, Kufeld M, Acker G, Lukas M, Grün A, Kalinauskaite G, Budach V, Waiser J and Stromberger C: Robotic stereotactic ablative radiotherapy for renal cell carcinoma in patients with impaired renal function. BMC Urol 19(1): 96, 2019. PMID: 31638979. DOI: 10.1186/s12894-019-0531-z

27 Yamamoto T, Kadoya N, Takeda K, Matsushita H, Umezawa R, Sato K, Kubozono M, Ito K, Ishikawa Y, Kozumi M, Takahashi N, Katagiri Y, Onishi H and Jingu K: Renal atrophy after stereotactic body radiotherapy for renal cell carcinoma. Radiat Oncol 11: 72, 2016. PMID: 27229710. DOI: 10.1186/s13014-016-0651-5

28 Kaplan ID, Redrosa I, Martin C, Collins C and Wagner A: Results of a phase I dose escalation study of stereotactic radiosurgery for primary renal tumors. Int J Radiat Oncol Biol Phys 78(3): S191, 2010. DOI: 10.1016/j.ijrobp.2010.07.464

29 Nair VJ, Szanto J, Vandervoort E, Cagiannos I, Breau R, Malone C, Avruch L, Pantarotto J and Malone S: CyberKnife for inoperable renal tumors: Canadian pioneering experience. Can J Urol 20(5): 6944-6949, 2013. PMID: 24128835.

30 McBride SM, Wagner AA and Kaplan ID: A phase 1 dose escalation study of robotic radiosurgery in inoperable primary renal cell carcinoma. Int J Radiat Oncol Biol Phys 87(2): S84, 2013. DOI: 10.1016/j.ijrobp.2013.06.218

31 Wang YJ, Han TT, Xue JX, Chang DS, Li HQ, Li P, Wang JD, Wang YJ and Xia TY: Stereotactic gamma-ray body radiation therapy for asynchronous bilateral renal cell carcinoma. Radiol Med 119(11): 878-883, 2014. PMID: 24696288. DOI: 10.1007/s11547-014-0402-3

32 Lo CH, Huang WY, Chao HL, Lin KT and Jen YM: Novel application of stereotactic ablative radiotherapy using CyberKnife ${ }^{\circledR}$ for early-stage renal cell carcinoma in patients with pre-existing chronic kidney disease: Initial clinical experiences. Oncol Lett 8(1): 355-360, 2014. PMID: 24959276. DOI: 10.3892/ol.2014.2129

33 Funayama S, Onishi H, Kuriyama K, Komiyama T, Marino K, Araya M, Saito R, Aoki S, Maehata Y, Nonaka H, Tominaga L, Muramatsu J, Nakagomi H, Kamiyama M and Takeda M: Renal Cancer is Not Radioresistant: Slowly but continuing shrinkage 
of the tumor after stereotactic body radiation therapy. Technol Cancer Res Treat 18: 1533033818822329, 2019. PMID: 30803362. DOI: $10.1177 / 1533033818822329$

34 Atwell TD, Carter RE, Schmit GD, Carr CM, Boorjian SA, Curry TB, Thompson RH, Kurup AN, Weisbrod AJ, Chow GK, Leibovich BC, Callstrom MR and Patterson DE: Complications following 573 percutaneous renal radiofrequency and cryoablation procedures. J Vasc Interv Radiol 23(1): 48-54, 2012. PMID: 22037491. DOI: 10.1016/j.jvir.2011.09.008

35 Ierardi AM, Puliti A, Angileri SA, Petrillo M, Duka E, Floridi C, Lecchi $M$ and Carrafiello G: Microwave ablation of malignant renal tumours: intermediate-term results and usefulness of RENAL and mRENAL scores for predicting outcomes and complications. Med Oncol 34(5): 97, 2017. PMID: 28421553. DOI: 10.1007/s12032-017-0948-8

36 Siva S, Ellis RJ, Ponsky L, Teh BS, Mahadevan A, Muacevic A, Staehler M, Onishi H, Wersall P, Nomiya T and Lo SS: Consensus statement from the International Radiosurgery Oncology Consortium for Kidney for primary renal cell carcinoma. Future Oncol 12(5): 637-645, 2016. PMID: 26837701. DOI: 10.2217/ fon. 16.2

37 Ortiz-Alvarado $\mathrm{O}$ and Anderson JK: The role of radiologic imaging and biopsy in renal tumor ablation. World J Urol 28(5): 551-557, 2010. PMID: 20419303. DOI: 10.1007/s00345-010$0549-\mathrm{z}$

38 Siva S, Callahan J, Pryor D, Martin J, Lawrentschuk N and Hofman MS: Utility of ${ }^{68} \mathrm{Ga}$ prostate specific membrane antigen - positron emission tomography in diagnosis and response assessment of recurrent renal cell carcinoma. J Med Imaging Radiat Oncol 61(3): 372-378, 2017. PMID: 28116853. DOI: 10.1111/1754-9485.12590

39 De Wolf K, Vermaelen K, De Meerleer G, Lambrecht BN and Ost $\mathrm{P}$ : The potential of radiotherapy to enhance the efficacy of renal cell carcinoma therapy. Oncoimmunology 4(10): e1042198, 2015. PMID: 26464810. DOI: 10.1080/2162402X.2015.1042198

40 Ishiyama H, Teh BS, Ren H, Chiang S, Tann A, Blanco AI, Paulino AC and Amato R: Spontaneous regression of thoracic metastases while progression of brain metastases after stereotactic radiosurgery and stereotactic body radiotherapy for metastatic renal cell carcinoma: abscopal effect prevented by the blood-brain barrier? Clin Genitourin Cancer 10(3): 196-198, 2012. PMID: 22409865. DOI: 10.1016/j.clgc.2012.01.004

41 Motzer RJ, Escudier B, McDermott DF, George S, Hammers HJ, Srinivas S, Tykodi SS, Sosman JA, Procopio G, Plimack ER, Castellano D, Choueiri TK, Gurney H, Donskov F, Bono P, Wagstaff J, Gauler TC, Ueda T, Tomita Y, Schutz FA, Kollmannsberger C, Larkin J, Ravaud A, Simon JS, Xu LA, Waxman IM, Sharma P and CheckMate 025 Investigators: Nivolumab versus everolimus in advanced renal-cell carcinoma. N Engl J Med 373(19): 1803-1813, 2015. PMID: 26406148. DOI: $10.1056 /$ NEJMoa1510665

42 Motzer RJ, Tannir NM, McDermott DF, Arén Frontera O, Melichar B, Choueiri TK, Plimack ER, Barthélémy P, Porta C, George S, Powles T, Donskov F, Neiman V, Kollmannsberger CK, Salman P, Gurney H, Hawkins R, Ravaud A, Grimm MO,
Bracarda S, Barrios CH, Tomita Y, Castellano D, Rini BI, Chen AC, Mekan S, McHenry MB, Wind-Rotolo M, Doan J, Sharma P, Hammers HJ, Escudier B and CheckMate 214 Investigators: Nivolumab plus Ipilimumab versus Sunitinib in Advanced Renal-Cell Carcinoma. N Engl J Med 378(14): 1277-1290, 2018. PMID: 29562145. DOI: 10.1056/NEJMoa1712126

43 Rini BI, Plimack ER, Stus V, Gafanov R, Hawkins R, Nosov D, Pouliot F, Alekseev B, Soulières D, Melichar B, Vynnychenko I, Kryzhanivska A, Bondarenko I, Azevedo SJ, Borchiellini D, Szczylik C, Markus M, McDermott RS, Bedke J, Tartas S, Chang YH, Tamada S, Shou Q, Perini RF, Chen M, Atkins MB, Powles $\mathrm{T}$ and KEYNOTE-426 Investigators: Pembrolizumab plus Axitinib versus sunitinib for advanced renal-cell carcinoma. N Engl J Med 380(12): 1116-1127, 2019. PMID: 30779529. DOI: 10.1056/NEJMoa1816714

44 McDermott DF, Lee JL, Szczylik C, Donskov F, Malik J, Alekseev BY, Larkin JMG, Matveev VB, Gafanov RA, Tomczak P, Tykodi SS, Geertsen PF, Wiechno PJ, Shin SJ, Pouliot F, Alonso T, Li W, Perini RF, Schloss C and Atkins MB: Pembrolizumab monotherapy as first-line therapy in advanced clear cell renal cell carcinoma (accRCC): Results from cohort A of KEYNOTE-427. J Clin Oncol 36(15_suppl): 4500-4500, 2018.

45 Hanna KS: A review of checkpoint inhibitors in the management of renal cell carcinoma. J Oncol Pharm Pract 26(2): 445-458, 2020. PMID: 31631812. DOI: 10.1177/1078155219881178

46 Luke JJ, Lemons JM, Karrison TG, Pitroda SP, Melotek JM, Zha Y, Al-Hallaq HA, Arina A, Khodarev NN, Janisch L, Chang P, Patel JD, Fleming GF, Moroney J, Sharma MR, White JR, Ratain MJ, Gajewski TF, Weichselbaum RR and Chmura SJ: Safety and clinical activity of pembrolizumab and multisite stereotactic body radiotherapy in patients with advanced solid tumors. J Clin Oncol 36(16): 1611-1618, 2018. PMID: 29437535. DOI: $10.1200 / J C O .2017 .76 .2229$

47 Masini C, Iotti C, De Giorgi U, Bellia RS, Buti S, Salaroli F, Zampiva I, Mazzarotto R, Mucciarini C, Vitale MG, Bruni A, Lohr F, Procopio G, Caffo O, Nole F, Morelli F, Baier S, Buttigliero C, Ciammella P, Timon G, Fantinel E, Carlinfante G, Berselli A and Pinto C: Nivolumab (NIVO) in combination with stereotactic body radiotherapy (SBRT) in pretreated patients (pts) with metastatic renal cell carcinoma (mRCC): First results of phase II NIVES study. J Clin Oncol 38(6_suppl): 613-613, 2020.

48 Hammers H, Vonmerveldt D, Ahn C, Nadal RM, Drake CG, Folkert MR, Laine AM, Courtney KD, Brugarolas J, Song DY, Hannan R and Carducci MA: Combination of dual immune checkpoint inhibition (ICI) with stereotactic radiation (SBRT) in metastatic renal cell carcinoma (mRCC) (RADVAX RCC). J Clin Oncol 38(6_suppl): 614-614, 2020. 